\title{
Variation in wood properties among five full-sib families of Norway spruce (Picea abies)
}

\author{
Arne STEFFENREM ${ }^{\mathrm{a} *}$, Pekka SARANPä ${ }^{\mathrm{b}}$, Sven-Olof LUNDQVIST ${ }^{\mathrm{c}}$, Tore SKR SPPA $^{\mathrm{a}}$ \\ a The Norwegian Forest and Landscape Institute, PO Box 115, 1431 Ås, Norway \\ ${ }^{\mathrm{b}}$ Finnish Forest Research Intstitute, PO Box 18, 01301 Vantaa, Finland \\ ${ }^{c}$ STFI-Packforsk, PO Box 5604, 11486 Stockholm, Sweden
}

(Received 27 November 2006; accepted 11 May 2007)

\begin{abstract}
Genetic- and environmental variation and correlation patterns were characterized for modulus of elasticity (MOE), modulus of rupture (MOR) and related wood traits: latewood proportion, wood density, spiral grain, microfibril angle and lignin content in five full-sib families of Norway spruce. The families were evaluated on the basis of clearwood specimens from the juvenile -mature wood transition zone of 93 sampled trees at age 30 year from seed. Family-means varied significantly $(p<0.05)$ for all wood traits studied except lignin content. MOE varied between $7.9-14.1$ GPa among trees and 9.4-11.0 GPa among families. MOR varied between 47-87 MPa among trees and 61-71 MPa among families. Families remained significantly different in an analysis of specific MOE (MOE/density) and MOR (MOR/density). Hence, solely relying on wood density as a wood quality trait in tree breeding would not fully yield the potential genetic gain for MOE and MOR. Correlations between wood structural traits and specific MOE and MOR are presented and discussed.
\end{abstract}

genetic variation / wood quality / modulus of elasticity / modulus of rupture / tree improvement

Résumé - Variabilité des propriétés du bois pour cinq familles de pleins-frères d'épicéa commun (Picea abies). La variabilité génétique et environnementale pour le module d'élasticité (MOE), le module de rupture (MOR) et certaines autres propriétés de base du bois (proportion de bois final, densité du bois, angle du fil, angle des microfibrilles et teneur en lignine) ont été étudiées au sein de cinq familles de pleins-frères d'épicéa commun ainsi que la liaison entre caractères. L'analyse a été réalisée à partir d'échantillons sans défaut issus de la zone de transition entre bois juvenile et bois mature de 93 arbres âgés de 30 ans (depuis la graine). Des différences significatives $(p<0.05)$ entre familles ont été observées pour tous les caractères sauf pour la teneur en lignine. Les valeurs de MOE variaient entre 7.9-14.1 GPa entre arbres et entre 9.4-11.0 GPa entre familles. Pour MOR, ces valeurs s'échelonnaient entre 47-87 MPa entre arbres et entre 61-71 MPa entre familles. Les différences entre familles pour MOE et MOR sont restées significatives après normalisation pour la densité du bois. Il est noté que l'utilisation seule de la densité du bois comme critère de sélection ne permettrait pas d'obtenir les gains génétiques potentiels escomptés d'une sélection directe pour MOE et MOR. Les corrélations entre propriétés de base du bois et les valeurs normalisées de MOE et MOR sont présentées et discutées.

variabilité génétique / propriétés du bois / module d'élasticité / module de rupture / amélioration génétique

\section{INTRODUCTION}

The versatility of the wood and its large geographic distribution makes Norway spruce (Picea abies (L.) Karst.) a widely used tree species in the European forest industry. It is utilized in a vast number of products including load carrying constructions, panelling, furniture, paper and other fiber products. Many end-uses require that forest production yields wood of good mechanical properties expressed in stiffness, strength and dimensional stability. Since the required rate of return from investments calls for fast growth and short rotations, this can be in conflict with interests in high quality.

Tree breeding programs aim to provide forestry with genetically improved reproductive materials. The programs, which traditionally have focused on climatic adaptation and volume production, could in addition emphasize on wood quality traits. This, however, requires knowledge about the genetic

* Corresponding author: arne.steffenrem@skogoglandskap.no variation in these traits and the genetic correlations among the traits.

Mechanical stiffness and strength of wood must be considered as composite traits that depend on physical, chemical and anatomical properties of wood. Consequently, genetic variation in such properties can theoretically be related to the basic factors causing genetic variation in stiffness and strength.

According to many reports, wood density is the most important trait controlling wood stiffness and strength (summarized in [50]). It has a strong and positive correlation with both tensile- and compression strength (summarized in [20]) but wood density is only moderately correlated with wood stiffness. This is particular the case with juvenile wood [2]. In addition, the orientation of the cellulose microfibrils in the S2 layer of the cell wall (MfA), has been shown to be an important trait characterizing wood stiffness in softwoods $[2,4,7,9,29]$. The effect of MfA seems to be considerable on tensile elasticity and strength [38] while its effect is less important on 
compression strength [11]. The effect of spiral grain on stiffness and strength is reported to be considerable when grain angles of mature wood exceed $3^{\circ}$ in spruce [31,49]. Spiral grain is more important for tensile- than compression strength (summarized in [20]). Lignin is an important cell wall compound but its effect on strength and stiffness is hardly ever reported in literature. Gindl and Teischinger [11] reported of a weak positive correlation with compression strength.

Density is the most frequently studied wood quality trait in genetic studies of Norway spruce. Previous studies show that its heritability is intermediate to high and that genotype by environment interaction is low $[3,13]$. Unfortunately, the genetic correlation with growth rate is reported to be negative [18], implying that selection for growth rate could reduce wood density in the long run. Little is known about genetic variation in MfA and its correlations with growth rate in Norway spruce, but Hannrup et al. [13] found intermediate broad sense heritability values and no genetic correlations with growth. Heritability for spiral grain in Norway and Sitka spruce has been reported to be intermediate to high, the genotype by environment interaction low, and the genetic correlation with growth weak [3,13-16]. Lignin content is summarized to be under strong genetic control, although the range of variation is small [50].

Hannrup et al. [13] studied how the joint effects of several wood quality traits add up to wood stiffness when they estimated low broad sense heritability values for wood stiffness in clones of Norway spruce. This is in contradiction to reports of intermediate to high narrow sense $[23,24]$ and high broad sense heritability [28] reported for radiata pine (Pinus radiata).

Forest tree improvement based on artificial selection methods rely on the existing genetic variation to achieve genetic gain. However, the knowledge regarding genetic variation within natural stands of Norway spruce is very limited for traits affecting wood quality. In addition, knowledge about how wood quality traits correlate genetically with each other and with growth rate is scarce and sometimes contradicting. Hence, the on-going selection for growth traits might cause unintentional adverse effects on wood quality. The aim of this study was to characterize the genetic variation and correlation patterns for clearwood modulus of elasticity (MOE) and rupture (MOR) among offspring from a natural Norway spruce stand grown in a long term progeny test.

\section{MATERIALS AND METHODS}

Controlled crosses were performed in the spring of 1973 in a natural stand of Norway spruce at Veldre in Ringsaker, $\left(61^{\circ} 00^{\prime} \mathrm{N}, 11^{\circ}\right.$ 00 ' E, at $500 \mathrm{~m}$ elevation) in southern Norway. Pollen was collected from ten randomly selected trees with both male and female flowers standing at least $50 \mathrm{~m}$ apart, and controlled pollinations were made with all pollen lots on female flowers on the same ten trees. This complete diallel mating included reciprocal crosses and self-pollinations [10]. In addition, open pollinated seed was collected from the selected trees. A detailed description of the stand and the crossing procedures is given by Skrøppa and Tho [44].
Table I. Traits investigated with abbreviations used in text, units of measurement and total number of observations.

\begin{tabular}{lccc}
\hline Trait & Abbreviation & Unit & $N$ \\
\hline Tree height & Height & $\mathrm{m}$ & 93 \\
Diameter at breast height & DBH & $\mathrm{cm}$ & 93 \\
Average ring width & RW & $\mathrm{mm}$ & 92 \\
Latewood proportion & LWP & $\%$ & 92 \\
Wood density at 12\% RH & Density & $\mathrm{kg} \mathrm{m}^{-3}$ & 93 \\
Spiral grain angle & Spiral grain & degrees & 85 \\
Microfibril angle & MfA & degrees & 93 \\
Lignin proportion & Lignin & $\%$ & 93 \\
Modulus of elasticity & MOE & $\mathrm{GPa}$ & 93 \\
Modulus of rupture & MOR & $\mathrm{MPa}$ & 87 \\
\hline
\end{tabular}

The seed lots were sown and germinated in the spring of 1974. In 1976, two years from seed, a half diallel of 45 full-sib families was planted together with 10 open pollinated families and three control seed lots in a long term progeny trial at Bjugstad in Gjøvik $\left(60^{\circ}\right.$ $50^{\prime} \mathrm{N}, 10^{\circ} 40^{\prime} \mathrm{E}$, at $350 \mathrm{~m}$ elevation). Each family was replicated in 12 blocks. Randomly within each block, each family was planted in a square four-tree plot. This design is a randomized complete block experiment (summarized in [30]). Each block contained 232 trees and with a $2.0 \mathrm{~m}$ spacing the size of the blocks were nearly $1 / 10$ of ha. The trial has not been subject to any thinning, fertilizing or pruning until 2001 when some trees from the open pollinated families were sampled for a genetic study of branching traits (unpublished master thesis).

Five genetically independent full-sib families located next to the diagonal in the mating design were selected in 2003. From these families intermediate or co-dominant trees that had no visible major damages or rot, and were not edge trees of large gaps, were sampled. Thus, the sampling was not completely random. In addition to $\sim 5 \%$ mortality and edge effects, the sampling restrictions made it impossible to sample all five families from all blocks. This imbalance was controlled by dividing the trial into three sampling units based on tree height. Each unit of four blocks is aimed to be as homogenous as possible in respect to site quality. Five to seven trees from each family were randomly selected within each sampling unit.

The trees were felled, and tree height and diameter at breast height $(\mathrm{DBH})$ were recorded. Two succeeding internodes were collected between 2 and $3 \mathrm{~m}$ above ground. This sampling height was chosen to avoid basal sweep and thereby reaction wood. The upper internode collected was analysed in this study. A number of traits were measured and an overview of the traits and their abbreviations are given in Table I. Some of the samples were too damaged after the destructive MOR test to measure spiral grain. Therefore the sample size is lower for this trait.

Boards, sized $20 \times 20 \times 340 \mathrm{~mm}$, were sawn from the transition between juvenile and mature wood on the north facing side of stem. One board was studied per log. The exact radial position of each sample was described as the distance and number of rings from the pith. The moisture content of the samples was stabilised at $12 \%$ relative moisture content by storing them at $20{ }^{\circ} \mathrm{C}$ and $65 \%$ relative humidity for a minimum of two weeks. The dimensions of the samples were measured with a digital caliper and their weights were determined in order to obtain the weight density values $(\rho 12)$. Longitudinal MOE and MOR were determined by a four-point bending test [21] according to Saranpää and Repola [40]. Load was applied in the tangential direction with a modified Lloyd universal testing machine (England). 
Six boards had internodal branches that were considered to affect MOR. These boards were removed from the material. Specific MOE and MOR were calculated as MOE/density and MOR/density respectively.

Lignin content was estimated by Fourier transform infrared (FTIR) spectroscopy [34]. Principal component regression (PCR) models were built for predicting the relative amount of lignin in wood analysed with the FTIR spectroscopy. The method was calibrated with the total lignin amounts determined with the Klason method [6]. The calibrated model was tested with an independent estimation data set. The model was then applied for predicting of lignin content in the samples in our material that can be regarded as very similar to those in the estimation data. Lignin content was determined on sections representing wood from pith to bark on the south facing side of stem.

After MOE and MOR testing, a $12 \mathrm{~mm}$ piece of wood was sawn as close to the fracture as possible and MfA was measured by the X-ray diffractiometry method implemented in the SilviScan-3 [8] at STFI-Packforsk in Sweden.

The reflected light intensity method implemented in WinDendro [37] was used to asses ring width (RW) and latewood proportion (LWP) on the radial surface of the boards. The demarcation between earlywood and latewood in each ring was set to be the point where light intensity was $30 \%$ of the difference between the minimum and maximum within ring light intensity. This demarcation criterion would resemble the $2 / 3$ rd of maximum-minimum wood density threshold often used for Norway spruce [19].

The grain angle (spiral grain) was measured by pulling a needle attached to an arm along the pith- and bark facing side of the boards. The needle followed the grain and left a track in the wood. The angle of this track relative to the longitudinal direction of the boards was measured by a protractor in degrees. The mean of the pith- and bark facing readings was used in the analysis.

\section{Data analysis}

The analyses of growth traits are here based on measurements only on sampled trees. The family-mean correlation between the height of all trees in trial and sampled trees was 0.96 , which indicate that the families were well represented by the sampled trees.

Analyses of variance and covariance were performed for all traits, including specific MOE and MOR, based on the type III sum of squares in SAS PROC GLM [43]. The coefficient of variation (CV) was calculated as $\left(\sqrt{M S_{E}} / \bar{y}\right) \cdot 100$. Since wood properties are known to vary rapidly with increasing distance from pith in the juvenile wood of conifers $[1,5,22]$, distance from pith to the location of the extracted boards was treated as a covariate in all analysis of RW, LWP, density, spiral grain, MfA, MOE and MOR. Total mean, $p$-value and $\mathrm{CV}$ are reported.

General mixed models for analysis of variance and covariance used were,

$$
y_{i j n}=\mu+\alpha_{i}+\gamma_{j}+\beta X_{i j n}+\alpha \gamma_{i j}+\varepsilon_{i j n}
$$

where, $y_{i j n}$ is the observation on the sample from tree $n$ in family $i$ in block $j . \mu$ is the total mean, $\alpha_{i}$ is the fixed effect of family $i, \gamma_{j}$ is the random effect of the blocks, $\beta X_{i j n}$ is the covariate term of which $X$ is the observed distance from pith for the sample from tree $n$ in family $i$ in block $j, \alpha \gamma_{i j}$ is the random interaction between family $i$ and block $j$ and $\varepsilon_{i j n}$ is the random residual. The random terms are assumed to
Table II. Total means, $p$-values, and coefficient of variation $(\mathrm{CV})$ from the analysis of variance and covariance. Covariate (distance to pith) indicated by "_" was not analysed for respective trait. Effects significantly different from $0(p \leqslant 0.05)$ is indicated in bold types.

\begin{tabular}{lcccccc}
\hline & & \multicolumn{5}{c}{ Model terms } \\
\cline { 3 - 6 } Trait & Mean & Distance & Family & Block & Family $\times$ Block & CV \\
\hline Height & 12.7 & - & $<\mathbf{0 . 0 0 1}$ & $\mathbf{0 . 0 0 2}$ & $\mathbf{0 . 0 0 7}$ & 5.8 \\
DBH & 14.3 & - & 0.13 & $\mathbf{0 . 0 4}$ & $<\mathbf{0 . 0 0 1}$ & 9.5 \\
RW & 3.2 & 0.09 & 0.76 & $\mathbf{0 . 0 3}$ & 0.19 & 16.0 \\
LWP & 29.0 & 0.73 & $\mathbf{0 . 0 2}$ & 0.06 & 0.36 & 15.2 \\
Density & 410 & 0.19 & $\mathbf{0 . 0 2}$ & $<\mathbf{0 . 0 0 1}$ & 0.43 & 6.5 \\
Spiral grain & 1.0 & 0.90 & $\mathbf{0 . 0 0 4}$ & 0.69 & $\mathbf{0 . 0 2}$ & 69.9 \\
MfA & 11.2 & 0.51 & $\mathbf{0 . 0 5}$ & 0.88 & 0.71 & 21.7 \\
Lignin & 25.5 & - & 0.12 & 0.55 & $\mathbf{0 . 0 0 2}$ & 2.1 \\
MOE & 10.3 & 0.19 & $\mathbf{0 . 0 0 3}$ & $\mathbf{0 . 0 0 5}$ & 0.46 & 10.1 \\
MOE/density & 0.025 & 0.72 & $\mathbf{0 . 0 0 9}$ & 0.83 & 0.41 & 8.1 \\
MOR & 66.7 & 0.55 & $\mathbf{0 . 0 0 2}$ & $\mathbf{0 . 0 0 4}$ & 0.38 & 9.6 \\
MOR/density & 0.16 & 0.47 & $<\mathbf{0 . 0 0 1}$ & 0.30 & 0.78 & 5.4 \\
\hline
\end{tabular}

have expectation equal zero and respective variances. The covariate term was not included in the model when analyzing height, DBH and lignin content. There was no difference whether distance to pith was measured in metric units or as ring number from pith. Therefore only the metric distance is used. Since more than one tree could have been sampled from each family in the same block, the $\alpha \gamma_{i j}$ estimates the plot effect. The plot effect was not significant for any of the wood quality traits investigated.

Least-squares means (LS-means) for families and best linear unbiased predictior (BLUP) [17] for blocks were computed according to the mixed model (1) in SAS PROC MIXED [43]. Phenotypic-, family-mean- and environmental correlations where then estimated by computing Pearson correlation coefficients based on phenotypic values, LS-means and BLUP values, respectively, in SAS PROC CORR [43].

\section{RESULTS}

The estimated production potential varied from 11 to $15 \mathrm{~m}^{3}$ $\mathrm{ha}^{-1} \mathrm{y}^{-1}$ [47] among blocks. This affected height and DBH with significant variation among blocks $(p<0.05)$ (Tab. II). There were significant differences among families for height $(p<0.001)$ but not for DBH $(p=0.13)$ and the most vigorously growing family had $10 \%$ higher height than the average of all families. Family by block interaction (plot effects) was significant for both traits $(p<0.01)$.

The variation in the radial distance from clearwood specimen to pith did not prove to be a significant regressor for any of the traits analysed ( $p>0.05)$ (Tab. II).

Significant differences among families $(p<0.05)$ were found for LWP, density, spiral grain and MfA but not for RW and lignin content (Tab. II). Significant variation among blocks were found for RW and density $(p<0.05)$ and almost for LWP ( $p=0.06)$. Of the traits showing significant family variation, only spiral grain had a significant plot effect.

The CVs for the majority of the traits varied between 2 and 22\% (Tab. II). However, the CV for spiral grain was high $(\sim 70 \%)$ indicating a very high experimental error. 

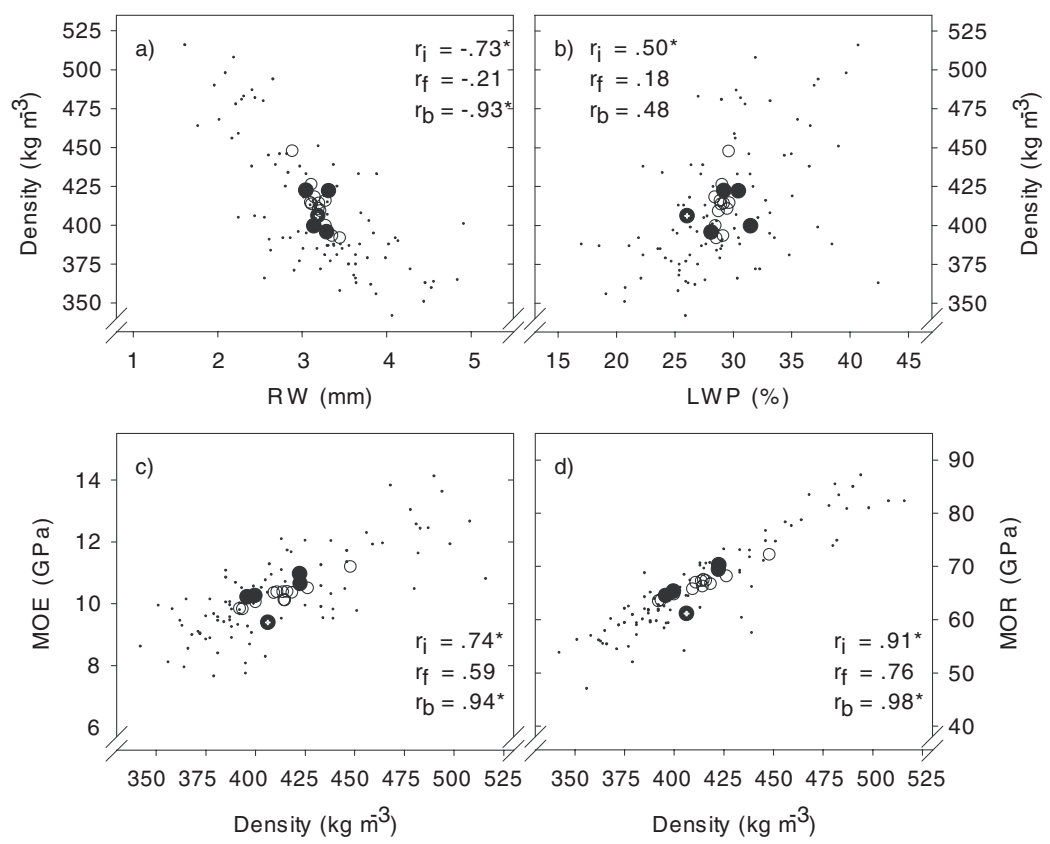

Figure 1. The relationship between (a) RW and density, (b) LWP and density, (c) density and MOE and (d) density and MOR on three levels: individual tree (.), family mean $(\bullet)$ and block mean $(\mathrm{o})$. Pearson correlation coefficients for individual tree $\left(r_{i}\right)$, family-mean $\left(r_{f}\right)$ and blockmean $\left(r_{b}\right)$ correlations are shown. Coefficients marked with $*$ are significantly different from $0(p \leq 0.05)$. A family that broke with several correlations is indicated $(\boldsymbol{\bullet})$.

There were highly significant differences among families for MOE and MOR $(p<0.01)$ (Tab. II). There were also significant variation among blocks $(p<0.01)$ but no significant plot effect existed $(p \approx 0.4)$. The family variation remained significant when the analysis was performed on specific MOE and MOR $(p<0.01)$. The variation due to blocks did, however, vanish completely $(p>0.3)$ and the CVs were reduced by $2 \%$ points for MOE and nearly $5 \%$ points for MOR.

\section{Correlations}

Relationships among traits are presented on three levels in Figure 1. These levels are: individual tree, family-mean and block-mean level. Since no variation among blocks was found for specific MOE and MOR, no block means based on BLUP could be estimated. Hence, the analysis of relationships between wood structural traits and specific MOE and MOR are based on individual tree and family-mean level correlations (Figs. 2 and 3).

The negative individual tree correlation between RW and density $\left(r_{i}=-0.73\right)$ had its parallel in the very strong and negative block-mean correlation $\left(r_{b}=-0.93\right)$ (Fig. 1a). The correlations between LWP and density were positive but somewhat weaker than what was the case for RW (Fig. 1b). The blockmean correlation $\left(r_{b}=0.48\right)$ was on the same magnitude as the individual tree correlation $\left(r_{i}=0.50\right)$. The family-mean correlations for RW and LWP with density were weaker the but showed the same sign $\left(r_{f}=-0.21\right.$ and $r_{f}=0.18$, respectively).
The individual tree correlation between density and MOE was moderate $\left(r_{i}=0.74\right.$, Fig. 1c) compared to the very strong correlation between density and MOR $\left(r_{i}=0.91\right.$, Fig. $\left.1 \mathrm{~d}\right)$. The block-mean correlations were very strong in both cases $\left(r_{b}>0.94\right)$. The family-mean correlations were in general weaker since one family in particular broke with this relationship $\left(0.59<r_{i}<0.76\right)$. This family is indicated in all figures.

There were strong correlations between MOE and MOR for individual trees $\left(r_{i}=0.89\right)$, family-means $\left(r_{f}=0.94\right)$ and block-means $\left(r_{b}=0.94\right)$ (data not shown).

Weak, but significant $(p \leqslant 0.05)$ and negative individual tree correlations were found for specific MOE with MfA and lignin (Figs. 2b and 2c), and for specific MOR with LWP and lignin (Figs. 3a and 3c). The family-mean correlations were not significant $(p>0.05)$ and in some cases contradicting the individual tree correlations in respect to the sign. The correlation between MfA and specific MOE (and MOR), e.g., was negative on individual tree level but positive on family mean level.

Spiral grain was negatively correlated with both specific MOE and MOR on individual tree level (Figs. $2 \mathrm{~d}$ and $3 \mathrm{~d}$, respectively), but the correlation was weak and not significant $(p \approx 0.25)$. The family-mean correlations were, however, very strong $\left(r_{f}>-0.93\right)$ and significant $(p \leqslant 0.05)$.

\section{DISCUSSION}

The variations in wood quality traits within a stand of Norway spruce would be due to both environmental and genetic origin. The results clearly show that there exists significant 


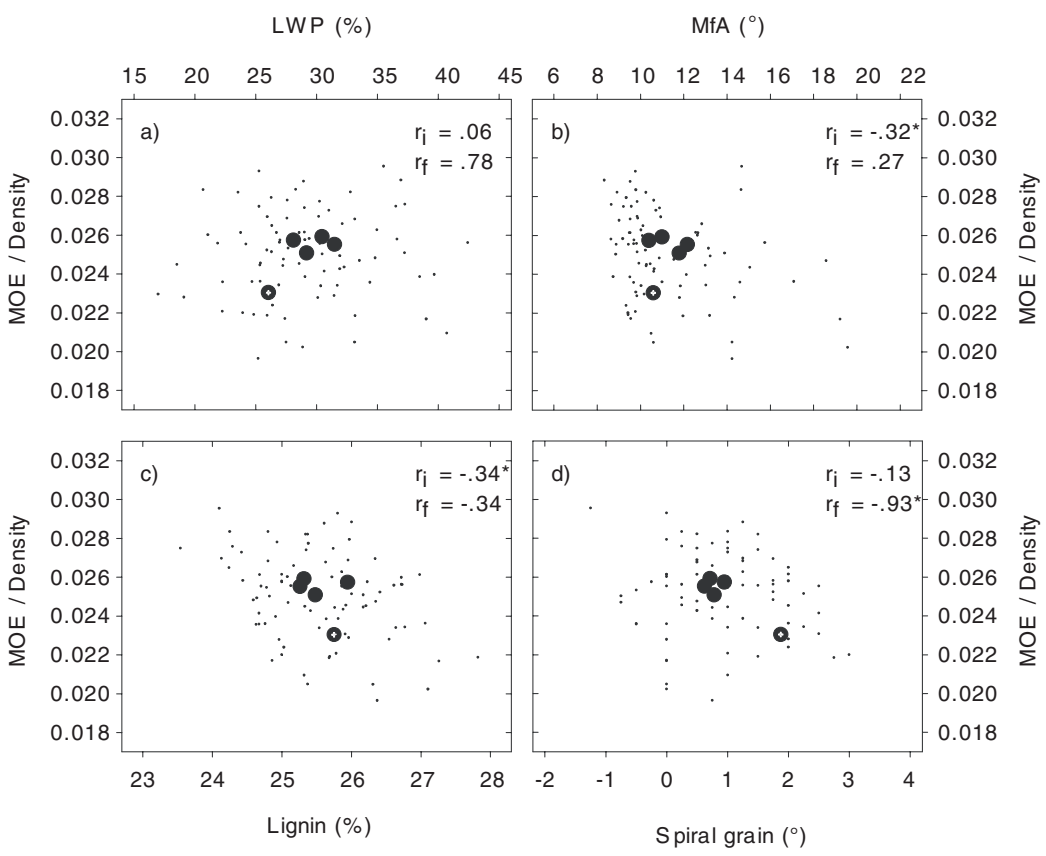

Figure 2. The relationship between specific MOE (MOE/density) and (a) LWP, (b) MfA, (c) lignin and (d) spiral grain on individual tree level (.) and family mean level $(\bullet)$. Pearson correlation coefficients for individual tree $\left(r_{i}\right)$ and family mean $\left(r_{f}\right)$ correlations are shown. Coefficients marked with * is significantly different from $0(p \leqslant 0.05)$. A family that broke with several correlations is indicated $(\bullet)$.

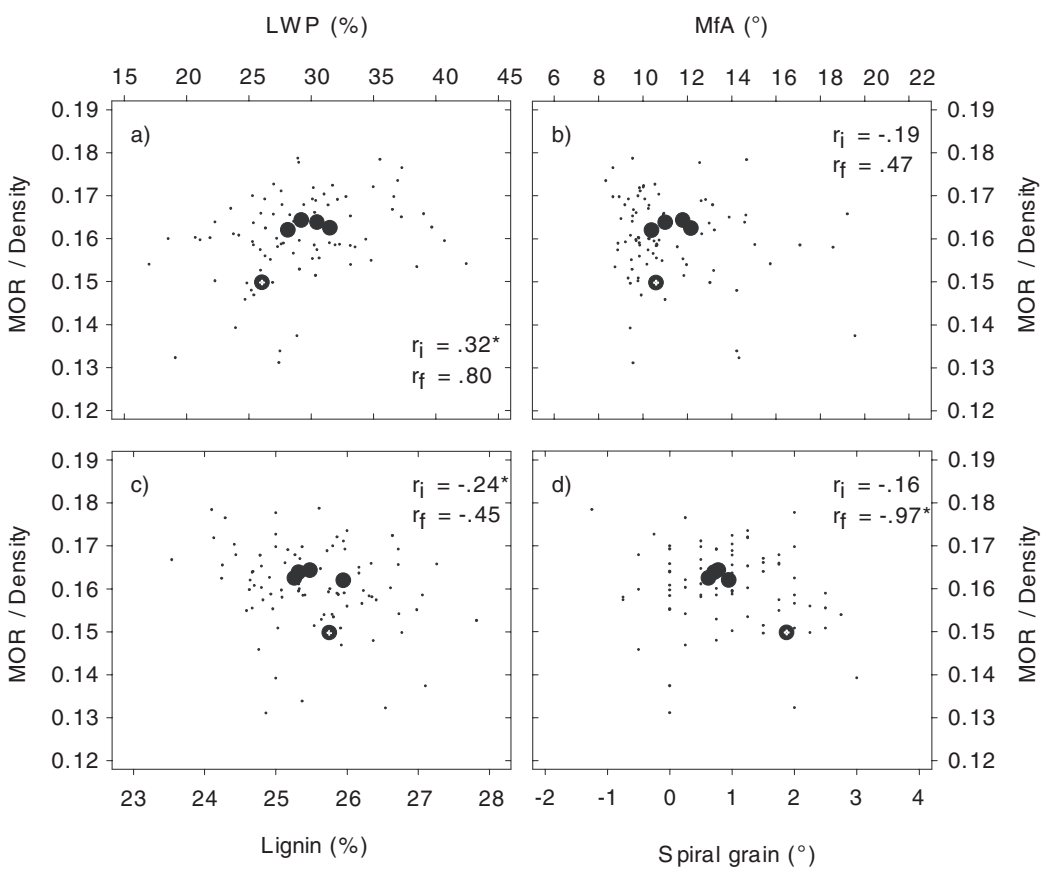

Figure 3. The relationship between specific MOR (MOR/density) and a) LWP, b) MfA, c) lignin and d) spiral grain on individual tree level (.) and family mean level $(\bullet)$. Pearson correlation coefficients for individual tree $\left(r_{i}\right)$ and family mean $\left(r_{f}\right)$ correlations are shown. Coefficients marked with * is significantly different from $0(p \leqslant 0.05)$. A family that broke with several correlations is indicated $(\bullet)$. 
environmental and genetic variation for clearwood MOE and MOR in progenies from a natural stand of Norway spruce. The relationships between density and MOE and MOR are well known [20]. Since the dependency of density on the mechanical properties of wood often is regarded to be functional, normalization by dividing with sample density is often used (e.g. $[9,29])$. However, the family variation persists even when the normalized traits, specific MOE and MOR, were analyzed. Hence, genetic variation in traits correlated with MOE and MOR, other than density, is likely to contribute to the observed genetic variation in MOE and MOR.

The genetic variation found for wood traits is supported by earlier reports of significant genetic variation in Norway spruce for LWP $[13,18]$, wood density $[3,13,18]$, spiral grain $[3,13]$ and MfA [13]. The low variation found for lignin content is supported by earlier results from trials with sexually reproduced families of Norway spruce [13], but contradicting the high broad sense heritabilities obtained from clones [13]. The latter study does also discuss whether the inheritance could predominantly be non-additive which would explain the contradicting results obtained from families and clones. In addition, results from eucalyptus (Eucalyptus globulus) [33] indicate that the degree of genetic control might be different for different types of lignin.

After 27 years in field there were significant family differences in height but not in DBH. DBH and RW were only intermediately correlated ( $r_{i}=0.60$, data not shown). RW was measured on the boards and since these only represent a part of the diameter RW can only indirectly be seen as a growth parameter in this study.

\subsection{Correlations}

Correlations based on the measured values on individual trees, phenotypic correlations, include all genetic and environmental variation [48]. The block-mean correlations based on BLUP are environmental correlations caused by differences between blocks in factors such as growth conditions and competition. Family-mean correlations based on LS-means are adjusted for the imbalanced sampling of families across blocks. It is however not fully a genetic correlation and caution must be taken when drawing conclusions based on a material with only five families.

Wood density is a physical property that is directly related to tracheid width, tracheid wall thickness and the wallto-lumen ratio of the tracheids [36]. These characteristics are again closely related to radial growth (RW) since the proportion of latewood (LWP) tends to decrease with increasing ring width (RW) $[32,39]$. The phenotypic correlation between RW and LWP were only intermediate $\left(r_{i}=-0.42\right.$, data not shown) and density correlated stronger with RW (Fig. 1a) than with LWP (Fig. 1b). It could be discussed if the light intensity method used in WinDendro [37] could introduce some experimental error which makes correlations with LWP vague in this material.

The results support that density has large impact on MOE (Fig. 1c) and MOR (Fig. 1d). The relatively stronger influence of density on MOR compared to MOE is supported by e.g. Saranpää and Repola [40] and Raiskila et al. [35]. The environmental correlation between RW and density is very strong $\left(r_{b}=-0.93\right)$ and so is the correlations between density and both MOE and MOR $\left(r_{b}>0.94\right)$. Hence, the environmental variation found for MOE and MOR can be attributed to the effect environment has on diameter growth and consequently wood density. This conclusion is supported by the results of the analysis of variance; the significant variation among blocks for MOE and MOR vanished when analyzing specific MOE and MOR.

There seems to be some negative impact of MfA on specific MOE (Fig. 2b) and MOR (Fig. 3b) even if it is less significant in comparison to the findings in loblolly and radiata pine $[4,29]$. However, the observed MfA values, with a mean of $11^{\circ}$ and a variation from $8^{\circ}$ to $20^{\circ}$, indicates that the majority of wood measured has reached maturity in respect to MfA [26, 41, 42]. The boards were extracted between ring 4 and cambium, which varied to be 13-21 rings from pith. This is in the transition zone between juvenile and mature wood in Norway spruce [5,22], or in the zones of juvenile corewood and juvenile transition wood according to Burdon et al. [1]. The maturity of the wood measured could partly explain the weak correlations with MOE, since also the reports from radiata pine indicate that MfA is more important in juvenile wood [4]. No phenotypic correlation between MfA and RW or density existed (data not shown) and since there were no effect of blocks in the analysis of variance (Tab. II), it can be concluded that the growth rate and site quality variation observed among blocks has no or very limited effect on MfA.

It is difficult to find support for the observed negative phenotypic correlation between lignin and specific MOE and MOR (Figs. 2d and 3d, respectively) in the literature. The contrary was reported by Gindl and Teischinger [11] when they found a weak, but significant, positive relationship between compression strength and lignin content. Since the cell structure in earlywood contains higher proportions of lignin-rich middle lamella than latewood (summarized in [20]), the effect of lignin on MOE and MOR could be confounded with other correlated traits such as RW, LWP and density.

There is one family that in some cases weakens and in other cases strengthens the family-mean correlations compared to the phenotypic and environmental correlations. This family is indicated in Figures 1-3. This particular family has lower MOE and MOR than what would be expected in relation to its density (Figs. 1c and 1d). The family has lower LWP (Fig. 1b) than the rest, but most striking is the higher spiral grain (Figs. 2d and 3d). The scatter plots (Figs. 2d and $3 d$ ) show that this family is relatively alone about causing the strong negative relationship between spiral grain and specific MOE and MOR on family-mean level. Increased spiral grain is expected to reduce MOE and MOR [20]. But the limited number of families and the low spiral grain values observed do not allow for any definite conclusions.

Mild compression wood is likely to occur to some extent in wood samples extracted near the juvenile wood in Norway spruce. Compression wood is known to contain more lignin, have higher density and MfA and have lower MOE and MOR 
than normal wood [46]. Since the highest MfA values observed in this material is lower than $20^{\circ}$ it is unlikely that compression wood had strong influence on the results.

\subsection{Implications for breeding}

The ten parent trees in the diallel mating design were selected to sample the genetic variation in a natural stand of Norway spruce in this region of Norway. This survey had to be limited to a subset of the families in the half diallel planted at Bjugstad. The five families analysed here is the highest number of genetically independent families among the 45 families and can not fully represent the total genetic variation in the natural stand. Nevertheless, our results show that wood density alone might not be sufficient as a wood quality selection criterion in a tree improvement program. Wood density is correlated with stiffness and strength, but this trait could not explain all the variation observed among families. This suggests that other traits, such as spiral grain, MfA and lignin content, could cause genetic variation in MOE and MOR. Hence, implementation of wood quality traits in breeding programs for Norway spruce should not alone rely on density measurements. Improvement of spiral grain and MfA is in addition likely to have a positive effect on shape stability in lumber from Norway spruce [45].

Clearwood MOE and MOR are direct measurements of wood quality traits that are important for the utilization of wood in load carrying constructions. The strong correlations found between MOE and MOR, both on individual tree level and family-mean level, suggest that they can be treated as the same trait in practical tree breeding. By direct measurements of wood stiffness or MOE on standing trees in field [12,25,27], selection for improved wood strength would be possible independently of whether the variation is caused by wood density or other underlying traits. Differences were found among families within a natural stand of Norway spruce, indicating that there is genetic variation present that can be utilized to improve the future wood quality by the means of tree breeding.

Acknowledgements: This study was supported by a grant from the Nordic Forest Research Co-operation Committee. The diallel experiment was initially established by Jon Dietrichson. We would like to thank: Björn Hannrup for initiating and leading the project; Tapio Järvinen, Tapio Nevalainen and Kari Sauvala for sample preparation and determing MOE and MOR; Irmeli Luovula for analysing the FTIR samples; Åke Hansson and Örjan Hedenberg for preparing and analysing the samples on SilviScan-3; Christian Kierulf for collecting the samples in field; the forest owner, Hans Bjugstad for all cooperation; Øystein Johnsen for comments and feedback on manuscript.

\section{REFERENCES}

[1] Burdon R.D., Kibblewhite R.P., Walker J.C.F., Megraw R.A., Evans R., Cown D.J., Juvenile versus mature wood: A new concept, orthogonal to corewood versus outerwood, with special reference to Pinus radiata and P. taeda, For. Sci. 50 (2004) 399-415.

[2] Cave I.D., Walker J.C.F., Stiffness of wood in fast-grown plantation softwoods - The influence of microfibril angle, For. Prod. J. 44 (1994) 43-48.
[3] Costa e Silva J., Borralho N.M.G., Wellendorf H., Genetic parameter estimates for diameter growth, pilodyn penetration and spiral grain in Picea abies (L.) Karst, Silvae Genet. 49 (2000) 29-36.

[4] Cown D.J., Hébert J., Ball R., Modelling radiata pine lumber characteristics. Part 1: Mechanical properties of small clears, N.Z. J. For. Sci. 29 (1999) 203-213.

[5] Danborg F., Juvenile wood in Norway and sitka spruce. Anotomy, density, drying properties, visual grading and strength properties, Forskningsserien nr. 18-1996, Forskningscenteret for Skov \& Landskap, Hørsholm, 1996, 1996, pp. 1-40.

[6] Dence C.W., The Determination of lignin, in: Lin S.Y., Dence C.W. (Eds.), Methods in Lignin Chemistry, Springer-Verlag, Heidelberg, 1992, pp. 33-61.

[7] Downes G.M., Nyakuengama J.G., Evans R., Northway R., Blakemore P., Dickson R.L., Lausberg M., Relationship between wood density, microfibril angle and stiffness in thinned and fertilized Pinus radiata, Iawa J. 23 (2002) 253-265.

[8] Evans R., A variance approach to the X-ray diffractometric estimation of microfibril angle in wood, Appita J. 52 (1999) 283-289, 294.

[9] Evans R., Ilic J., Rapid prediction of wood stiffness from microfibril, angle and density, For. Prod. J. 51 (2001) 53-57.

[10] Fins L., Friedman S.T., Brotschol J.V., Handbook of quantitative forest genetics, Kluwer Academic Publishers, London, 1992.

[11] Gindl W., Teischinger A., Axial compression strength of Norway spruce related to structural variability and lignin content, Compos. Part A - Appl. Sci. Manuf. 33 (2002) 1623-1628.

[12] Grabianowski M., Manley B., Walker J.C.F., Acoustic measurements on standing trees, logs and green lumber, Wood Sci. Technol. 40 (2006) 205-216.

[13] Hannrup B., Cahalan C., Chantre G., Grabner M., Karlsson B., Le Bayon I., Jones G.L., Müller U., Pereira H., Rodrigues J.C., Rosner S., Rozenberg P., Wilhelmsson L., Wimmer R., Genetic parameters of growth and wood quality traits in Picea abies, Scand. J. Forest Res. 19 (2004) 14-29.

[14] Hannrup B., Grabner M., Karlsson B., Müller U., Rosner S., Wilhelmsson L., Wimmer R., Genetic parameters for spiral-grain angle in two 19-year-old clonal Norway spruce trials, Ann. For. Sci. 59 (2002) 551-556.

[15] Hansen J.K., Roulund H., Genetic parameters for spiral grain, stem form, pilodyn and growth in 13 years old clones of Sitka spruce (Picea sitchensis (Bong.) Carr.), Silvae Genet. 46 (1997) 107-113.

[16] Hansen J.K., Roulund H., Genetic parameters for spiral grain in two 18 -year-old progeny trials with Sitka spruce in Denmark, Can. J. For. Res. 28 (1998) 920-931.

[17] Henderson C.R., Selection index and expected genetic advance, in: Hanson W.D., Robinson H.F. (Eds.), Statistical genetics and plant breeding, National Academy of Sciences and National Research Council, Publ. No. 982, Washington, DC, 1963, pp. 141-163.

[18] Hylen G., Genetic variation of wood density and its relationship with growth traits in young Norway spruce, Silvae Genet. 46 (1997) $55-60$.

[19] Hylen G., Age trends in genetic parameters of wood density in young Norway spruce, Can. J. For. Res. 29 (1999) 135-143.

[20] Kollmann F.F.P., Côté Jr. W.A., Principles of wood science and technology. I. Solid wood, Springer-Verlag, Berlin, 1968.

[21] Kučera B., Skandinaviske normer for testing av små feilfrie prøver av heltre, Skogforsk, Norwegian Forest Research Institute, Ås, 1992.

[22] Kučera B., A hypothesis relating current annual height increment to juvenile wood formation in Norway spruce, Wood Fiber Sci. 26 (1994) 152-167.

[23] Kumar S., Genetic parameter estimates for wood stiffness, strength, internal checking, and resin bleeding for radiata pine, Can. J. For. Res. 34 (2004) 2601-2610. 
[24] Kumar S., Dungey H.S., Matheson A.C., Genetic parameters and strategies for genetic improvement of stiffness in radiata pine, Silvae Genet. 55 (2006) 77-84.

[25] Kumar S., Jayawickrama K.J.S., Lee J., Lausberg M., Direct and indirect measures of stiffness and strength show high heritability in a wind-pollinated radiata pine progeny test in New Zealand, Silvae Genet. 51 (2002) 256-261.

[26] Lichtenegger H., Reiterer A., Stanzl-Tschegg S.E., Fratzl P., Variation of cellulose microfibril angles in softwoods and hardwoods - A possible strategy of mechanical optimization, J. Struct. Biol. 128 (1999) 257-269.

[27] Lindström H., Harris P., Nakada R., Methods for measuring stiffness of young trees, Holz Roh- Werkst. 60 (2002) 165-174.

[28] Lindström H., Harris P., Sorensson C.T., Evans R., Stiffness and wood variation of 3-year old Pinus radiata clones, Wood Sci. Technol. 38 (2004) 579-597.

[29] Megraw R., Bremer D., Leaf G., Roers J., Stiffness in loblolly pine as a function of ring position and height, and its relationship to microfibril angle and specific gravity, in: Nepveu G. (Ed.), Connection between silviculture and wood quality trough modelling approaches and simulation software, Proceedings of IUFRO WP S5.01-04 Third Workshop, La Londe-Les-Maures, France, 1999, pp. 341349.

[30] Montgomery D.C., Design and analysis of experiments, John Wiley \& Sons, inc., New York, 1997.

[31] Northcott P.L., The effect of spiral grain on the usefulness of wood, Forest Products Laboratory, Canada. Reprint from Proceedings of the meeting of IUFRO section 41, Melbourne, Australia, Vancouver, BC, 1965, pp. 1-18.

[32] Olesen P.O., The interrelation between basic density and ring width of Norway spruce, Rapport fra Det Forstlige Fors $\emptyset$ gsvæsen i Danmark 35 (1976) 340-359.

[33] Poke F.S., Potts B.M., Vaillancourt R.E., Raymond C.A., Genetic parameters for lignin, extractives and decay in Eucalyptus globulus, Ann. For. Sci. 63 (2006) 813-821.

[34] Raiskila S., Pulkkinen M., Laakso T., Fagerstedt K., Löija M., Mahlberg R., Paajanen L., Ritschkoff A.C., Saranpää P., FTIR spectroscopic prediction of Klason and acid soluble lignin variation in Norway spruce clones, Silva Fenn. 41 (2007) 351-371.

[35] Raiskila S., Saranpää P., Fagerstedt K., Laakso T., Löija M., Mahlberg R., Paajanen L., Ritschkoff A.C., Growth rate and wood properties of Norway spruce cutting clones on different sites, Silva Fenn. 40 (2006) 247-256.
[36] Rathgeber C.B.K., Decoux V., Leban J.-M., Linking intra-tree-ring wood density variations and tracheid anatomical characteristics in Douglas fir Pseudotsuga menziesii (Mirb.) Franco), Ann. For. Sci. 63 (2006) 699-706.

[37] Regent Instruments Inc., WinDendro 2002b, Regent Instruments Inc., Quebec, 2002.

[38] Reiterer A., Lichtenegger H., Tschegg S., Fratzl P., Experimental evidence for a mechanical function of the cellulose microfibril angle in wood cell walls, Philosophical Mag. A 79 (1999) 2173-2184.

[39] Saranpää P., Wood density and growth, in: Barnett J.R., Jeronimidis G. (Eds.), Wood quality and its biological basis, Blackwell Publishing \& CRC Press. Biological Sciences Series, 2003, pp. 87117.

[40] Saranpää P., Repola J., Strenght of Norway spruce from both mixed stands and monocultures, The Finnish For. Inst., Research Papers 822 (2001) 33-39.

[41] Sarén M.P., Serimaa R., Andersson S., Paakkari T., Saranpää P., Pesonen E., Structural variation of tracheids in Norway spruce (Picea abies [L.] Karst.), J. Struct. Biol. 136 (2001) 101-109.

[42] Sarén M.P., Serimaa R., Andersson S., Saranpää P., Keckes J., Fratzl P., Effect of growth rate on mean microfibril angle and crosssectional shape of tracheids of Norway spruce, Trees-Struct. Funct. 18 (2004) 354-362.

[43] SAS Institute Inc., SAS/STAT user's guide, version 9, SAS Institute Inc., Cary, NC, USA, 2003.

[44] Skrøppa T., Tho T., Diallel crosses in Picea abies. I. Variation in seed yield and seed weight, Scand. J. For. Res. 5 (1990) 355-367.

[45] Säll H., Spiral grain in Norway spruce, Acta Wexionesia 22/2002 (2002) 1-171.

[46] Timmel T.E., Compression wood in gymnosperms, SpringerVerlag, New York, 1986.

[47] Tveite B., Site-index curves for Norway spruce (Picea abies (L.) Karst), Meddelelser fra Norsk institutt for skogforskning 33 (1977) $1-84$.

[48] Van Buijtenen J.P., Fundamental genetic principles, in: Fins L., Friedman S.T., Brotschol J.V. (Eds.), Handbook of quantitative forest genetics, Kluwer academic publishers, Dordrecht, 1992, pp. 29-68.

[49] Wilson T.R.C., The effect of spiral grain on the strength of wood, J. For. XIX (1921) 740-747.

[50] Zobel B., van Buijtenen J.P., Wood variation: its causes and control, Springer-Verlag, Berlin, 1989. 